https://doi.org/10.31713/m1008

\title{
PROSPECTS OF METHANE MINING IN THE WESTERN REGION OF UKRAINE
}

\section{Chukharev S.M.}

National University of Water and Environmental Engineering (NUWEE), Ph.D. (Engineering), Associate Professor, Department of Development of Deposits and Mining, Ukraine

\section{Lozynskyi V.H.}

Dnipro University of Technology, Ph.D., Associate Professor, Department of Mining Engineering and Education, Ukraine

\section{Zaiets V.V.}

National University of Water and Environmental Engineering (NUWEE), Ph.D., Associate Professor, Department of Development of Deposits and Mining, Ukraine

\section{Solvar L.M.}

Chervonograd State College of Mining Technology and Economics, Director, Ukraine

\section{Okseniuk R.R.}

National University of Water and Environmental Engineering (NUWEE), Assistant, Department of Development of Deposits and Mining, Ukraine

\section{Summary}

Methane reserves of coal mines of Ukraine are analyzed, and comparisons with other coal mining countries of the world are made. It is determined that Ukraine is among the countries with the largest reserves of mine methane. Data on the need to reduce methane emissions and its negative impact as one of the main greenhouse gases on global warming and climate change are presented. The world experience of methane extraction and processing from coal mines is studied, the advantages and disadvantages of different types of methane neutralization are determined. The priority directions of this activity for Ukraine are determined.

\section{Introduction}

The problem of reducing methane emissions from coal mines into the atmosphere and its utilization, at the moment, is very acute around the world. The use and processing of methane from coal mines is an urgent scientific and applied task, the solution of which should significantly increase the environmental security of Ukraine, 
reduce global warming, create economic conditions for the development and transformation of the mining industry. To solve this problem associated with the extraction and utilization of methane, it is necessary to conduct research aimed at assessing the state of the industry and prospects for its development.

\section{General characteristics of methane from coal mines}

Much of the world's primary energy production is coal. As a result, industrialized countries are somewhat dependent on energy coal resources using coal as the main energy source.

Due to the growing dependence and increasing demand for coal in many countries around the world is increasing and its production. As a result, coal has to be mined in increasingly difficult conditions, as part of the shallow reserves is declining and as a result there is a need to develop coal mines, which are located at greater depths and are richer in gas.

Coal mining on ever lower horizons and with higher gas concentrations increases the already existing danger of carrying out these works for miners and enterprises in particular. Methane present in coal seams can cause explosions and accidents in mines, which is why technologies related to methane mining and utilization, degassing of coal mines and mine ventilation should be improved.

In addition to being explosive, methane is also released into the atmosphere, making it the second most common greenhouse gas after carbon dioxide $\left(\mathrm{CO}_{2}\right)$, which is largely released into the atmosphere by humans. The largest greenhouse gas is water vapor.

Methane as a greenhouse gas has existed in the atmosphere for about 9-15 years, which is why this gas is considered a "short-term climate-forming factor." Its share of global greenhouse gas emissions is about 14 percent. Although methane enters the atmosphere in smaller quantities than $\mathrm{CO}_{2}$ and remains in it for less time, its ability to retain heat in the atmosphere - the so-called "potential contribution to global warming" - is 21 times higher.

In addition to coal mining and transportation, methane is released during the production of natural gas and oil. In addition, it is formed in the process of decomposition of organic waste at municipal landfills, in some manure storage systems for farm animals and in a number of systems for treatment of agro-industrial and domestic wastewater. Methane emission control provides a unique opportunity not only to mitigate climate change, but also to obtain an additional 
source of energy. However, unless tougher measures are taken to reduce methane emission sources, by 2030 their volume will increase by about 45 percent and reach 8,522 million metric tons of carbon dioxide equivalent (million tons of $\mathrm{CO}_{2} \mathrm{e}$ ) [1].

According to preliminary estimates, methane resources in the world are estimated at 260 trillion $\mathrm{m}^{3}$. The largest reserves are concentrated in countries such as the United States, China, Russia, Australia, South Africa, India, Poland, Germany and Ukraine. It should be borne in mind that currently there is no single methodology that would determine the exact reserves of mine methane, so the data in different scientific or analytical sources may differ. The presence of methane in the main coal-mining countries of the world, according to one source, is given in the table. 1 [2].

Table 1

The amount of methane reserves in coal mines in major coal mining countries

\begin{tabular}{c|c}
\hline Country & Methane reserves, trillion $\mathrm{m}^{3}$ \\
\hline USA & 60 \\
\hline Russia & 58 \\
\hline China & 28 \\
\hline Australia Taria & 22 \\
\hline India & 18 \\
\hline Germany & 16 \\
\hline PAR & thirteen \\
\hline Ukraine & 8 \\
\hline Kazakhstan & 8 \\
\hline Poland & 3 \\
\hline Other & 26 \\
\hline Together in the world & 260 \\
\hline
\end{tabular}

Thus, as we see, Ukraine has significant reserves of methane concentrated in coal seams and surrounding rocks that could be used as energy. Data published in 2014 show that Donbass mines emit about 1.5 billion $\mathrm{m} 3$ of methane per year, and the Lviv-Volyn coal basin approximately 60 million $\mathrm{m}^{3}$. The share of methane used as gas fuel is only $8 \%$. All other gas is simply released into the atmosphere and pollutes the environment. In terms of the amount of carbon methane emissions into the atmosphere, Ukraine ranks fourth in the world, which is clearly demonstrated by the diagram shown in Fig. 1 [2] 


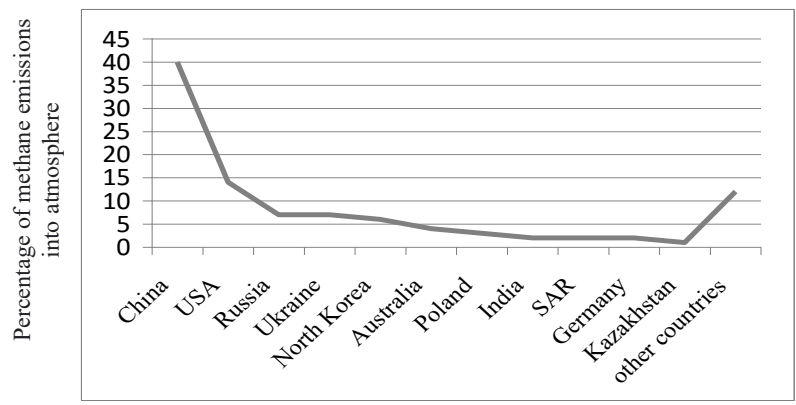

Fig. 1. The structure of mine methane emissions by major coal mining countries, \%: China - 40; USA-14; Russia - 7; Ukraine - 7; North Korea - 6; Australia - 4;

Poland - 3; India - 2; SAR - 2; Germany - 2; Kazakhstan - 1; other countries- 12

Since Ukraine has significant reserves of methane, its use and processing is an urgent scientific and applied task.

According to the Global Methane Initiative Table 2 (Global Methane Initiative, GMI), Ukraine also ranks 4th in the estimated amount of methane released from coal mines. In total, in 2010, about 584 million tons of $\mathrm{CO}_{2} \mathrm{e}$ were released from the world's coal mines, or $8 \%$ of global emissions of this gas [1].

$\mathrm{CO}_{2} \mathrm{e}$ or $\mathrm{CO}_{2}$ equivalent is the global warming potential of a given greenhouse gas, the amount of which is equal to the amount of $\mathrm{CO}_{2}$ with the same global warming potential.

Table 2

Estimated volume of methane released from coal mines in the countries of the top ten GMI in 2010

\begin{tabular}{c|c}
\hline The country & Million tons of $\mathrm{CO}_{2} \mathrm{e}$ \\
\hline China & 299.5 \\
\hline USA & 59.0 \\
\hline Russia & 55.2 \\
\hline Ukraine & 27.4 \\
\hline Australia & 26.8 \\
\hline India & 26.5 \\
\hline Kazakhstan & 13.5 \\
\hline Poland & 8.3 \\
\hline Colombia & 7.4 \\
\hline Vietnam & 6.0
\end{tabular}


According to the Ministry of Energy and Coal Industry, in 2012, 1.4 billion $\mathrm{m}^{3}$ of mine methane was extracted from 85.7 million tons of coal. The main amount of methane through the ventilation systems of the mines got into the atmosphere and only 370 million $\mathrm{m}^{3}$ was captured by degassing systems, which at that time were equipped with only 44 mines out of 155 . But that's not all, only $43 \%$ of the captured methane was subsequently 'utilized or burned on a torch, and the rest also entered the atmosphere.

It is also worth noting that at the moment part of the Donbass is occupied, and therefore it is impossible to provide more relevant information on methane emissions throughout Ukraine.

The problem of reducing methane emissions and its utilization is very acute at the moment. Its use and processing is an urgent scientific and applied task, the solution of which will significantly increase the ecological security of the country, will have an impact on the planet's climate, and may also have a certain economic effect. To solve this problem associated with the extraction and utilization of methane, it is necessary to conduct scientific and research work aimed at assessing the state of the industry and prospects for its development.

\section{Problems and prospects of methane mining in the coal industry}

To determine the prospects for methane extraction from coal mines, it is necessary to take into account the world experience of other countries that also have certain methane reserves in coal mining and have made certain investments and have already started mining and utilization of mine methane.

The previous section shows Table 1, where the reserves of methane from coal seams in the world's coal-mining countries should be noted that Ukraine is not a leader in world reserves: The United States - 60 trillion $\mathrm{m}^{3}$, Russia -58 trillion $\mathrm{m}^{3}$, China - 28 trillion $\mathrm{m}^{3}$, Australia - 22 trillion $\mathrm{m}^{3}$, India - 18 trillion $\mathrm{m}^{3}$, Germany 16 - trillion $\mathrm{m}^{3}$, South Africa - 13 trillion $\mathrm{m}^{3}$, Ukraine -8 trillion $\mathrm{m}^{3}$, Kazakhstan -8 trillion $\mathrm{m}^{3}$, Poland -3 trillion $\mathrm{m}^{3}$, others -26 trillion $\mathrm{m}^{3}$.

Therefore, considering the experience of other countries, it is worth paying attention to the successful cases not only of leaders in stocks, but especially countries that have a similar or smaller number of stocks than ours. 
In Poland, coalbed methane is concentrated in the deposits of the three Lublin Basin (which is a continuation of the Lviv-Volyn Basin), Lower Silesia and Upper Silesia, and their forecast reserves are 15 and 1.75 and 89.1 billion $\mathrm{m}^{3}$, respectively. At the Zofiówka mine in Silesian Voivodeship, there is a thermal power plant, where the new unit installed in 2018 burns methane along with coal, which covers $10 \%$ of fuel needs and is cheaper than using natural gas. The thermal power plant produces electricity, heat and compressed air (supplied to the mine) [3].

The Czech Republic and Belgium, which have lower methane reserves than Ukraine, also produce and process this gas. In particular, in the Czech Republic, more than 50 million $\mathrm{m}^{3}$ of degassing methane is used each year in boiler houses and coal drying plants. And in Belgium, methane is mined in deposits where coal is no longer mined. As for countries with large reserves of methane in coal seams such as the United States, China, Russia, Australia, they are actively implementing technologies aimed at degassing coal mines and methane processing, which indicates the potential for its extraction. For example, in China in 2005 production was 3-4 billion $\mathrm{m}^{3}$, and in $2010 \mathrm{p}$. this figure was 10 billion $\mathrm{m}^{3}$ [3].

The Energy Strategy of Ukraine until 2030 states that the extraction of 1 ton of coal emits an average of $10-12 \mathrm{~m}^{3}$ of methane. In some deposits in the Donbass, the specific content of methane in coal reaches $500 \mathrm{~m}^{3} / \mathrm{t}$.

As for the Lviv-Volyn coal basin, the projected reserves of hydrocarbon gases in coal seams exceed 18.8 billion $\mathrm{m}^{3}$, and this figure may increase with the implementation of a more thorough study [4].

The total projected methane reserves in Ukraine, which are listed in this and the previous section, indicate the prospects for methane production from coal seams.

In the mining industry of Ukraine and the world there are constant problems with methane, which complicates coal mining. Due to the fact that the depth of extraction is constantly increasing and the amount of available methane in it. Because of what they are trying to reduce these emissions.

Coal mine methane is methane that is released from coal and the surrounding layers of rocks during mining operations. During 
underground coal mining, coal mine methane is explosive to miners, causing it to be removed from the mines through ventilation systems. In some cases, the ventilation system is supplemented by a degassing system, which consists of a network of wells and gas pipelines. In abandoned mines and either during opencast coal mining, methane can also be released into the atmosphere through natural cracks or other diffuse sources [5].

Methane in coal mines can be released from five sources, namely:

- $\quad$ in degassing systems at underground coal mines. When using these systems can use horizontal or vertical wells, as well as their combination for methane production before extracting the most mineral, this method is called "pre-mine drainage") or methane can be extracted after mining;

- $\quad$ together with ventilation air from underground mines, which contains a small percentage of methane;

- abandoned or closed mines. In this case, methane may be released through ventilation shafts or cracks in the ground, which arose as a result of mining or improper care of non-functioning mines;

- at open development of deposits. During this time, methane in the coal seams is directly exposed to the atmosphere;

- allocation (loss) as a result of processing and transportation of minerals. This process occurs after the mineral has been mined and coal continues to emit methane when it is stored in piles and transported.

\section{Methods of using methane from coal mines}

The availability of methane production technologies from coal mines allows us to consider a number of areas for the sale of methane and its products. There is no single specific consumer of mine methane in the world, because the directions of its use depend on a number of factors, the main of which is probably the quality of the extracted gas, the concentration of methane and the presence of other components. In addition to the quality of gas, no less important factors are the presence of certain end users and economic indicators of the project, which is aimed at the extraction and processing of methane. 
There are the following ways of using and processing mine methane in the world:

- for electricity generation. For example, you can consider the construction of TPP directly near the mines;

- for central heating, as boiler fuel or city gas;

- $\quad$ sold to natural gas pipeline systems;

- $\quad$ for drying coal;

- $\quad$ as a heat source for mine ventilation air;

- $\quad$ as additional fuel for mine boilers, or possible combustion in combination with other fuels;

- as a motor fuel in the form of compressed or liquefied natural gas;

- $\quad$ incineration and use in production or industry. For example, as raw materials for the production of gaseous carbon black, methanol, acetylene, ammonia and other substances;

- use in the field of fertilizer production;

- $\quad$ oxidation of methane and obtaining useful thermal energy for heating, refrigeration or electrical installations;

- use as a raw material in the fertilizer industry;

- for the conversion of coal into a gaseous energy carrier [6,7].

Consider the advantages and disadvantages of the main methods of using methane [8]:

- $\quad$ electricity production. This technology is probably one of the most common and can be used in gas engines, to provide power to mines or to supply electricity to the grid. The advantages of this method of application are that this technology is tested; waste heat recovery can be used to heat mine structures, shower rooms of miners, as well as to heat and cool the air of mine shafts. The disadvantages of this method are the high capital costs at the initial stage of project implementation; unstable electricity production;

- use as pipeline gas. High quality purified mine methane is used for this technology. The advantages of this method are that as a result of methane processing the equivalent of natural gas is obtained, and the application of this method can be quite profitable at high gas prices; it is better to apply where there is a strong pipeline infrastructure. The disadvantages of this method are the expensive process of methane purification; construction of pipeline infrastructure is required if it is absent. 
- use as urban or industrial gas of medium quality. These applications can be used for local district heating systems in residential areas and for industrial use, such as in industrial furnaces. The advantages of this method are to obtain a fuel source at a low price; cleaning may be minimal or non-existent. The disadvantages are the high cost of the distribution system and maintenance; uninterrupted supply; the need to build special gas storage facilities for regulation during peak needs;

- $\quad$ use of methane as a raw material for the chemical industry in particular. The possibility of using methane for the production of soot, synthetic fuels and other substances. The advantage of this method is the use of high-quality mine methane in difficult conditions. The disadvantages here may be the high cost of processing to obtain certain substances; the supply of certain substances on the market may not meet the demand;

- use on site of coal mining. In this way, it is possible to use methane in mine boilers, for drying coal, as a heat source for mine ventilation air, for heating houses adjacent to the mines. The advantages of this method are that methane can partially replace coal, and be environmentally friendly and cheap energy. The disadvantages of this method are that the amount of methane extracted will exceed the needs and, accordingly, not all methane will be used; may be less cost-effective to use at the location of the mine than outside it;

- $\quad$ use as automotive fuel in the form of compressed or liquefied natural gas. Advantages of the method there is free access to the market for gas supplies in difficult conditions; high prices for motor fuel. The disadvantages are high standards for cleaning; costs of gas processing, storage, injection and transportation.

Thus, as we see, there is a fairly wide range of uses of coalbed methane in industry for various needs of the national economy. The choice of methane use should be made taking into account the mining and geological characteristics of the extracted methane, as well as the needs of the region where the project of processing and utilization will be implemented.

And given the environmental aspect, namely that methane is a greenhouse and ozone-depleting gas, its use will have a positive effect in improving the environmental situation in Ukraine and the 
world, and the establishment of a mechanism for "emissions trading" under the Kyoto Protocol to the UN Framework Convention on Climate Change, can become an additional source of foreign exchange and foreign investment in our country, in particular in industrial regions.

Analyzing all the data presented in the previous section, the extraction and processing of methane from coal seams is a promising area of development of the mining industry.

The experience of coal-producing countries, where the utilization of coalbed methane is well developed, shows that methane production is possible and appropriate at three stages of mine development:

- before the extraction of minerals;

- $\quad$ in an abandoned or closed mine;

- at the existing mine.

Prior to the extraction of coal, gas can be extracted only with the use of methods that stimulate its desorption - directional drilling, fracturing, pumping water.

Gas pumping in existing mines in the process of coal mining is performed by the methods of current degassing, when due to the unloading of the coal mass from the pressure is the desorption of methane from coal and its filtration from the cracks of reservoirs. This method has already been implemented in Donbass, where the extraction of methane from coal mines took place by drilling underground wells and wells from the surface in the fields of existing mines, as well as degassing works.

After the extraction of coal, methane extraction, which fills the produced spaces of spent lavas and closed mines, is carried out by drilling wells. Then the methane is pumped out by vacuum pumps.

Methane from coal seams can be extracted as a stand-alone or as an associated mineral. In Ukraine, the method of extraction of methane as an associated mineral by the method of mine degassing in the extraction of the main mineral - coal, is done mainly not for the purpose of further processing of methane but to ensure gas safety [9].

Consider the implementation of projects for the extraction and processing of methane [1].

To implement a successful mine methane emission reduction project, the mine owner needs to address a range of issues, from 
project design to installation and operation. The success of the project requires a thorough examination of methane reserves and analysis of gas emissions, effective integration of degassing and utilization measures and the extraction process, as well as the availability of a market for methane. Despite the fact that in recent years there have been significant positive changes in the implementation of mine methane utilization projects, project participants may face a number of technical, economic and institutional problems that can hinder implementation. Among the important issues to consider are the following:

- methane should be seen as a useful and cost-effective product, not just a source of increased danger;

- the mine and project developers must have at their disposal modern state-of-the-art methane extraction systems, as well as the technologies and training facilities necessary for the use of this valuable resource;

- it is necessary to create an effective mechanism for collecting and disseminating reliable and unbiased information, including technical and market information;

- it is necessary to clarify the regulatory framework governing the collection and disposal of mine methane, and to address any issues related to possible violations or restrictions;

- $\quad$ it is necessary to provide access to the capital market.

Consider ways to process methane from coal mines in different directions.

Obtaining acetylene from coalbed methane. Acetylene can be obtained by thermal decomposition of coalbed methane at temperatures above $1500^{\circ} \mathrm{C}$. Depending on the method of heat supply to the reaction zone, different technologies of acetylene production are used: electro cracking, pyrolysis in a reactor with a nozzle, oxidative pyrolysis and pyrolysis in low-temperature plasma, homogeneous pyrolysis. A substance such as acetylene is used in the manufacture of raw materials for the production of plastics, synthetic rubber fibers, etc.

Obtaining carbon black from coalbed methane. Carried out by thermal decomposition of methane without access of air at an operating temperature of $1100{ }^{\circ} \mathrm{C}$ get soot. The advantages of this process are simplicity and relative cheapness, high soot yield, the 
formation of a quality by-product of gas with a high hydrogen content. The disadvantages of this method are the periodicity of the process and the heterogeneity of the resulting carbon black, which clearly reduces its quality. Soot is used in the manufacture of car tires, rubber products, printing industry, etc.

Chemical processing of methane into synthesis gas. The main direction of chemical processing of methane is currently the conversion into synthesis gas (which is a mixture of components $\mathrm{CO}$ and $\mathrm{H}_{2}$ ) on its basis is subsequently synthesized for ammonia, methanol, higher alcohols and other chemical elements that are valuable. The most advanced technologies are methane steam conversion, partial oxidation and autothermic reforming.

Catalytic oxidative dimerization of methane. Work in this direction has been carried out for almost 30 years, the process of catalytic oxidation of methane dimerization is not currently implemented in industry, but it seems quite promising. The temperature of this process is $850-950{ }^{\circ} \mathrm{C}$. However, the yield of the sum of the products of $\mathrm{C}_{2}$ (Ethylene + ethane) is small. Among the disadvantages of this process is the low productivity of the catalysts.

Method of direct oxidation of methane to methanol. Currently, two main options for the implementation of this process are technologically developed: cyclic and flow. It is better to use the cyclic process to carry out the most complete conversion of hydrocarbon gas in the absence of external consumers. The flow process is simpler from a technological point of view, it allows the use of air as an oxidant, which may be more cost-effective than the cyclic process. It is advisable to use flow if there is fuel natural gas nearby (for example, it can be a thermal power plant or a gas compressor station).

Given the needs of Ukraine in the production of additional electricity, more and more news about a possible energy crisis in the country due to insufficient coal at thermal power plants should consider technologies for processing methane from coal mines for electricity production.

Gas turbines are often used to convert methane into electricity. An example of whose work in different versions is considered in the work of V.I. Kharchenko, Wu Tai Thu, O.O. Filonenko, O.S. Kucherenko, A.Yu. Voloshin "Utilization of mine methane in a gas turbine installation" [10] the scheme of a gas turbine installation with a vacuum combustion chamber is shown in Figure 2. 


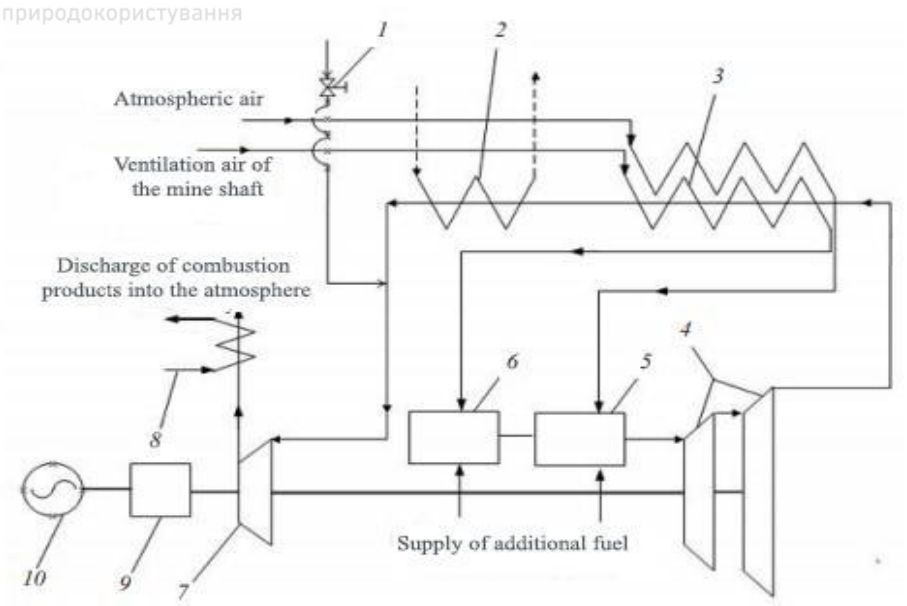

Fig.2. Gas turbine unit with vacuum combustion chamber with regenerative heating of atmospheric and ventilation air of the mine shaft

The principle of operation is that the ventilation air from the shaft of the mine is supplied to the regenerator 3 heat gases coming from the turbine. After that, the ventilation air through the concentrator 6 enters the combustion zone of the vacuum combustion chamber 5 , which can be supplied with additional methane to provide the fuel concentration required for continuous combustion. In the combustion zone, combustion products are formed with a temperature that is close to stoichiometric. Atmospheric air is supplied to the regenerator 3 heat gases from the turbine. Next, the air is supplied to the mixer of the vacuum combustion chamber 5 , moving with the high-temperature combustion products from the combustion zone and forming at the outlet of the vacuum combustion chamber combustion products of the desired temperature. From the vacuum combustion chamber, the combustion products are fed to the turbine 4 , and then to the regenerator 3 and the low-potential boiler 2. It should be noted that the temperature of the combustion products at the entrance to the vacuum compressor 7 decreases to $40^{\circ} \mathrm{C}$, while the water temperature in the low-potential boiler increases to $90^{\circ} \mathrm{C}$. In the vacuum compressor there is an increase in the pressure of the combustion products to the parameters that ensure the flow of gas through the boiler 8 and the device exhaust gas into the atmosphere. The water temperature in the boiler rises to $150^{\circ} \mathrm{C}$. Turbine 4 rotates 
the vacuum compressor 7 and through the reducer 9 - the generator 10. In hot water boilers begins to produce thermal energy, and in the electric generator, respectively, electricity. that the temperature of the combustion products at the entrance to the vacuum compressor 7 is reduced to $40^{\circ} \mathrm{C}$, while the water temperature in the low-potential boiler increases to $90^{\circ} \mathrm{C}$. In the vacuum compressor there is an increase in the pressure of the combustion products to the parameters that ensure the flow of gas through the boiler 8 and the device exhaust gas into the atmosphere. The water temperature in the boiler rises to $150^{\circ} \mathrm{C}$. The turbine 4 rotates the vacuum compressor 7 and through the reducer 9 - the electric generator 10. In hot water boilers begins to produce thermal energy, and in the electric generator, respectively, electric. that the temperature of the combustion products at the entrance to the vacuum compressor 7 is reduced to $40^{\circ} \mathrm{C}$, while the water temperature in the low-potential boiler increases to $90^{\circ} \mathrm{C}$. In the vacuum compressor there is an increase in the pressure of the combustion products to the parameters that ensure the flow of gas through the boiler 8 and the device exhaust gas into the atmosphere. The water temperature in the boiler rises to $150{ }^{\circ} \mathrm{C}$. Turbine 4 rotates the vacuum compressor 7 and through the reducer 9 - the generator 10 . In hot water boilers begins to produce thermal energy, and in the electric generator, respectively, electricity. which provide the flow of gas through the boiler 8 and the device exhaust gas into the atmosphere. The water temperature in the boiler rises to $150^{\circ} \mathrm{C}$. Turbine 4 rotates the vacuum compressor 7 and through the reducer 9 - the generator 10 . In hot water boilers begins to produce thermal energy, and in the electric generator, respectively, electricity. which provide the flow of gas through the boiler 8 and the device exhaust to the atmosphere. The water temperature in the boiler rises to $150^{\circ} \mathrm{C}$. Turbine 4 rotates the vacuum compressor 7 and through the reducer 9 - the generator 10 . In hot water boilers begins to produce thermal energy, and in the electric generator, respectively, electricity.

The procedure of formation of combustion products in the combustion chamber of the gas turbine unit is carried out in stages. The first stage assumes that in the combustion zone of the combustion chamber the fuel is burned together with the coefficient of excess air, which is close to unity, and the temperature close to 
stoichiometric. To do this, use part of the air that is taken from the compressor and enters the combustion zone of the combustion chamber. This part of the air is called the primary air.

During the second stage, in the mixing zone of the combustion chamber, the combustion products are mixed with the rest of the air from the compressor (i.e. secondary air) to the desired temperature of the combustion products at the inlet to the turbine of the gas turbine unit.

The ratio of primary air $G_{\text {ПЕРВ }}$ to the amount of air at the entrance to the combustion chamber $\mathrm{G}_{\mathrm{K} 3}$ can be expressed through the ratio of excess air coefficients in the combustion zone $\alpha_{\text {ПЕРВ }}$ and at the exit of the combustion chamber $\alpha_{\mathrm{K} 3}$. [10]

$$
\frac{G_{n е р в}}{G_{\kappa з}}=\frac{\alpha_{\text {перв }}}{\alpha_{\kappa з}} .
$$

Calculations for the formula. (1) indicate that when carrying out stoichiometric combustion of fuel in the combustion zone of the combustion chamber and the temperatures of the combustion products at the inlet to the turbine $1000-1100{ }^{\circ} \mathrm{C}$ the ratio $G_{\text {перв }} / G_{\text {кз }}=0.28-0.33$.

That is, in a gas turbine installation of the traditional scheme, it is useful to use only $28-33 \%$ of the mass of methane contained in the air of mine ventilation systems.

Taking into account the considered options of methane extraction and processing, as well as the prospects of such activities and resources of the Lviv-Volyn coal basin, we can offer a complex for degassing and processing of methane from coal mines by a gas turbine for electricity production in mines of Lviv-Volyn region.

The complex envisages methane extraction by current degassing for electricity production, and the use of ventilation methane for heat production (for the needs of the mine).

The schematic diagram of the complex can be seen in Figure 3. 


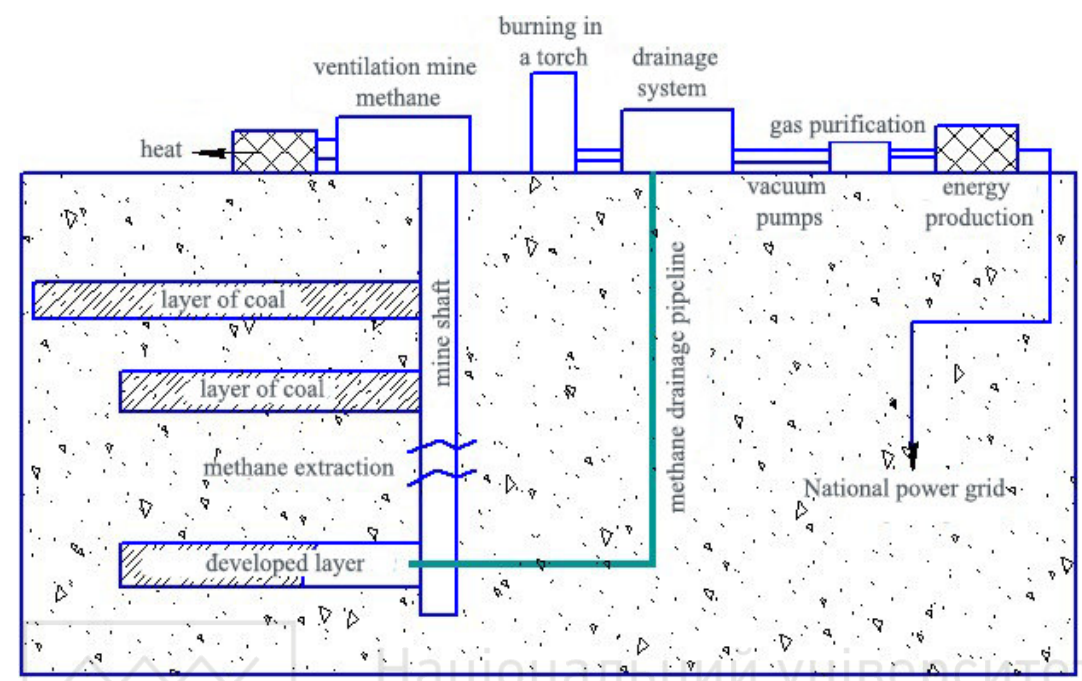

Fig. 3. Schematic diagram of the complex for degassing and methane processing of coal mines by a gas turbine unit for electricity generation

Methane extraction is envisaged by the methods of current degassing on already operating sections of the mine. For efficient extraction, a drainage system will be used from which the gas mixture will be fed to the gas purification through vacuum pumps. After that, the methane will enter the gas turbine plant in which the process of electricity production will take place, which will be supplied to the national grid.

It should be noted that this scheme does not exclude the possibility of introducing methods of methane production by predegassing.

In the conditions of mining operations, certain fluctuations may occur, which will relate to methane production, equipment for processing methane into electricity may malfunction or stop for maintenance of units. It is for such moments that it is proposed to burn gas in a flare, this will make it possible to minimize methane emissions.

Despite degassing during coal mining, small amounts of methane will still enter the workings and be removed by ventilation systems. Such methane will have a lower quality, so it is proposed to use it to produce heat for the needs of the enterprise. 
By implementing this complex in the Rivne-Volyn coal basin of Ukraine, it is expected to significantly reduce the release of methane into the atmosphere and make coal mining safer by reducing the possibility of sudden methane emissions. Methane processing for energy generation and heat production for the needs of the mine will bring the company economic income through the sale of energy and cost savings. Also, the introduction of new technologies for the use of methane increases the cost of the enterprise by generating capital that can be reinvested in equipment and measures to ensure the safety of the mine.

\section{Conclusions}

It is determined that Ukraine has significant resources of methane, which is found in coal seams and can be used as an alternative energy resource [11]. The quantitative analysis of methane reserves of coal mines in the leading countries of the world on coal mining is carried out.

Positive aspects have been identified that will reduce the environmental risk by reducing greenhouse gas emissions into the atmosphere, which is a source of increasing global warming; increase the safety of mining operations; will allow the use of mine methane as an energy resource.

On the basis of the considered modern directions of extraction and processing of methane of coal mines it is established that this direction is perspective, especially in needs of Ukraine on energy. The experience of other countries is analyzed and a comparison with the possibilities of Ukraine is made.

The review of technologies for extraction and processing of methane from coal mines is carried out in the work.

The scheme of the complex on degassing and processing of methane by the gas turbine installation for production of the electric power at mines of the Lviv-Volyn region is offered.

The complex also provides for the separate use of ventilation methane to generate heat, which is more appropriate to use in the needs of the enterprise. And given that the amount of methane produced is unstable, whether it is possible to stop electricity production for technical reasons, the excess gas is proposed to be disposed of through flare combustion, which is also provided in the proposed complex. 


\section{References}

1. Global Methane Initiative, GMI, (2011). Methane from coal mines: opportunities to reduce emissions, improve collection and disposal, September - $4 \mathrm{p}$.

2. E.S. Sai, K.A. Ganushevich, (2014). Utilization of mine methane and its transportation in the gas-hydrate state // Development of deposits: Coll. Science. pr .. - T. 8. - S. 299-307. - Bibliogr .: 15 titles. - Russian

3. Unconventional sources of hydrocarbons in Ukraine: a monograph. (2014). In 8 books. Book 1. Non-traditional sources of hydrocarbons: a review of the problem / [Kurovets IM etc.]; Nat. joint-stock company "Naftogaz of Ukraine", etc. - K.: NікаCenter, 2014. - 208 p. ISBN 978-966-521-654-4

4. Kostyk I., Matrofaylo M., Korol M. (2013). Prospects of modern natural gas potential of coal seams of deep horizons of the Lviv-Volyn basin. Geologist of Ukraine. 2013. № 3. S. 50-59

5. United States Environmental Protection Agency, Coal Mine Methane Sources, https://www.epa.gov/cmop/coal-mine-methane-sources

6. Malanchuk Z.R., Zayets V.V., Solvar L.M., Romanchuk S.S., (2016). Methods of conversion of coal into gaseous energy carrier at the place of occurrence, Bulletin of NUVGP series "Technical sciences" issue 2 (74)

7. Malanchuk Z.R., Zayets V.V., Solvar L.M., Romanchuk S.S., (2016). Underground gasification of coal deposits, Bulletin of NUVGP series "Technical Sciences" issue 2 (74)

8. European Economic Commission Methane - Markets Partnership (2010). Guide to Best Practices for Efficient Degassing of Methane Sources and Methane Utilization in Coal Mines, ECE Energy Series, 31, United Nations New York and Geneva

9. Yukhimchuk S.Ya., (2020). Analysis of the state of methane extraction and use in Ukraine, Student Bulletin of NUVGP, vol. 2 (14)

10. Kharchenko VI, Wu Tai Thu, Filonenko OO, Kucherenko OS, Voloshin A.Yu., (2011). Utilization of mine methane in a gas turbine unit, ELECTRONIC BULLETIN NUK • №1 •

11. Oksenyuk RR, Semenyuk VV, Yukhimchuk S. Ya., (2020). Evaluation of methane production and use in Ukraine, International scientific-practical conference of young scientists, graduate students and applicants for higher education "Problems and prospects for the development of modern science" Rivne, Art. 136-137. 